\title{
NIEMIECKIE FORTYFIKACJE TOMASZOWA MAZOWIECKIEGO I OKOLIC. TYPY I RODZAJE SCHRONÓW
}

\section{Wprowadzenie}

Historia regionalna stanowi często bezcenny punkt odniesienia dla badań prowadzonych w szerszym zakresie. Dzięki uwadze poświęconej wyselekcjonowanym, szczegółowym przykładom, a także dzięki osadzeniu ich w często unikalnych realiach danego terenu łatwiej jest zrozumieć problem w skali holistycznej. Niewątpliwie do najlepszych przykładów, wspierających zasadność powyższej tezy, należą dzieje fortyfikacji ${ }^{1}$. Wynika to $\mathrm{z}$ faktu, iż dane dzieło fortyfikacyjne było budowane i wykorzystywane - jak również zachowało się do naszych czasów - w konkretnym terenie. Teren, jego charakterystyka i ocena, stanowią ważny element sztuki planowania i dowodzenia wojennego. Realia terenowe determinują przemiany w szeroko pojętej sztuce wojennej. Powoduje to, iż rozwiązania przyjęte w danych realiach mogą okazać się zupełnie nieadekwatne do sytuacji panujących w innych.

Tematem rozważań zawartych na kartach niniejszego artykułu są fortyfikacje niemieckie z okresu II wojny światowej, zlokalizowane w okolicach Tomaszowa Mazowieckiego ${ }^{2}$. W okresie historycznym będącym zasadniczą cezurą chronologiczną artykułu, Tomaszów Mazowiecki był ośrodkiem przemysłowym (branża włókiennicza i chemiczna), wkomponowanym w malowniczy pejzaż rozlewiska

* Inż. Paweł Grad, historyk-regionalista, członek Polskiego Towarzystwa Historycznego, z zawodu geodeta. Archiwum Państwowe w Piotrkowie Trybunalskim, Oddział w Tomaszowie Mazowieckim, ul. Spalska 120, 97-200 Tomaszów Mazowiecki. E-mail: geograd@o2.pl

${ }^{1} \mathrm{Na}$ temat fortyfikacji niemieckich z okresu II wojny światowej powstały liczne publikacje, np. Rawski (1966); Kędryna, Jurga (1999); Szymańska, Szymański (2002; 2009); Łach (2002; 2014); Dudek, Sadowski (2006); Maszkowski (2010); Kaufmann, Kaufmann, Jurga (2011); Podsiadło (2012). W tym miejscu składam serdeczne podziękowania dr. Maciejowi Hubce za nieocenioną pomoc w napisaniu artykułu.

2 Przy opracowaniu tematu wykorzystano prace naukowe i popularno-naukowe (np. Bednarski 1995; Szymańska, Szymański 2012; Podsiadło 2014; Hubka 2016), a także materiały archiwalne i wartościowe strony internetowe (np. http://www.bunkierkonewka.eu, http://www.schrony.eu). 
rzeki Pilicy i jej dopływów. Rzeka ta nazwę swą wzięła od wartkiego nurtu i zmiennego profilu koryta - co czyniło z niej ważną przeszkodę terenową podczas działań wojennych. Pobliskie lasy spalskie - dawne tereny łowieckie rosyjski carów oraz rekreacyjne Prezydenta II RP - nie tylko urozmaicały krajobraz, lecz również zapewniały szybkie dostawy drewna na potrzeby prac fortyfikacyjnych. Skrócony zarys charakterystyki terenu, prowadzonej pod względem jego bogactw i warunków naturalnych, dopełniają złoża kruszyw szklarskich i budowlanych. Czynniki te z pewnością ułatwiały prowadzenie na większą skalę fortyfikacyjnego rozwinięcia terenu, zwłaszcza w okresie braków materiałowych osłabionej wojną gospodarki III Rzeszy.

Kolejną kwestią była sieć komunikacyjna - jej przedwojenny stan oraz wojenna rozbudowa. Tomaszów Mazowiecki w omawianym okresie w ogólnej ocenie pod tym względem wypadał na tle regionu korzystnie. Był on lokalnym węzłem komunikacyjnym, połączonym bitymi drogami z Łodzią oraz Piotrkowem. W omawianym czasie w mieście zlokalizowana była również stacja kolejowa. Stan infrastruktury ułatwiał zatem transport zarówno oddziałów wojskowych, jak również - co w kontekście tematu artykułu ważniejsze - surowców i prefabrykatów budowlanych.

Zanim jednak przejdziemy do meritum, warto zaznaczyć iż celem artykułu jest syntetyczne ukazanie niezwykle złożonego i trudnego badawczo tematu. Składają się nań niemieckiej fortyfikacje różnego typu i przeznaczenia, połączone wojenną historią regionu. Zagadnienia te dotychczas cieszyły się zainteresowaniem wąskiego kręgu specjalistów, którzy opublikowali szereg prac naukowych i popularnych ${ }^{3}$. Artykuł ten jest zatem również próbą zebrania w jednym miejscu efektów badań i dociekań, zarówno jego autora, jak i innych pasjonatów i badaczy omawianych zagadnień. Oparty jest on zarówno na powstałej w ostatnich latach literaturze, jak również na wykonanych przez autora kwerendach archiwalnych ${ }^{4}$.

Linia Pilicy jest to pas umocnień wybudowany przez Niemców w okresie od lata 1944 r. (prace na szeroką skalę ruszyły w sierpniu) do stycznia 1945 r. Piliza Stellung - jak występuje w zestawieniach - nie ma precyzyjnego odnośnika geograficznego ${ }^{5}$. Niniejsze opracowanie obejmuje odcinek znajdujący się na terenie dzisiejszych powiatów tomaszowskiego i piotrkowskiego (2015). Zaczyna się w miejscowości Lubocz (koło Rzeczycy), a kończy w Sulejowie.

Ślady umocnień widoczne są do dzisiaj, choć dużo lepiej widoczne były w latach pięćdziesiątych czy sześćdziesiątych dwudziestego wieku. Również inne,

${ }^{3}$ Por. zwłaszcza Rudź (1980); Bednarski M. (1995); Kobalczyk (2005); Ordak (2012); Szymańska, Szymański (2012); Matuszak (2014); Podsiadło (2014); Wróbel (2015); Hubka (2016).

${ }^{4}$ Nieocenioną pomocą okazał się przewodnik po zbiorach Archiwum Państwowego w Tomaszowie Mazowieckim (Hubka, Ordak, Wróbel 2010). Autor serdecznie dziękuje dr. Tomaszowi Matuszakowi, dyrektorowi Archiwum Państwowego w Piotrkowie Trybunalskim, za zgodę na wykorzystanie materiałów archiwalnych jako ilustracji w niniejszej publikacji (zob. ilustr. 1, 3-4).

${ }^{5}$ Por. Podsiadło (2014); Hubka (2016). 
pomniejsze świadectwa wojennych dziejów regionu jeszcze do niedawna wkomponowane były w życie codzienne jego mieszkańców. Hełmy niemieckie służyły za miski dla zwierząt lub czerpaki, a puszki po maskach przeciwgazowych za pojemniki na smar lub różne drobiazgi. Można było również bez większego problemu znaleźć amunicję, granaty i różne niewypały. Na wsiach wyposażenie pojazdów wojskowych lub ich części służyło przez wiele lat nawet w warsztatach mechanicznych ${ }^{6}$. Większość z tych rzeczy z biegiem czasu zużyła się, zardzewiała, została wymieniona na nowe, a stare pojechały do hut lub po prostu zostały wyrzucone. Dużo lepiej w walce z czasem wypadły umocnienia żelbetowe. Może nie wszystkie, bo część na pewno skruszono, aby zrobić miejsce „nowemu”. Część została po wojnie zabudowana i zaadaptowana do celów cywilnych, a część może znajdować się na terenie zakładów przemysłowych. Lecz nadal duża ich liczba zachowała się w terenie i tworzy ciekawostkę regionu, przyciągając turystów z całej Polski.

W latach 1940-1944 w okolicach Tomaszowa Mazowieckiego, Luboczy, Inowłodza i Sulejowa Niemcy wybudowali wiele obiektów fortyfikacyjnych. Powody były dwa: pierwszy to ulokowanie w Spale w 1939 roku Dowództwa Wojskowego na Wschodzie (Oberost), a drugi zagrożenie ofensywą Armii Czerwonej w 1944 r.

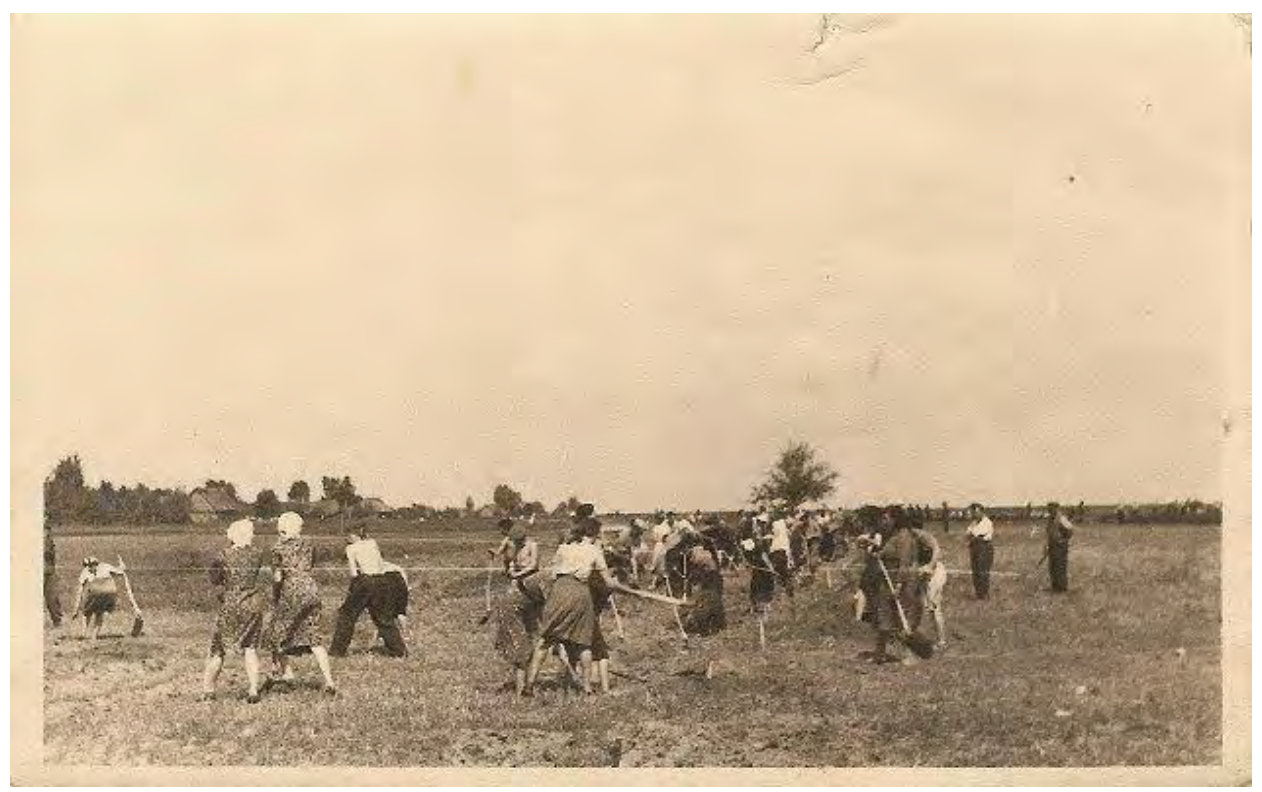

Ilustr. 1. Budowa pozycji obronnych.

Źródło: Archiwum Państwowe w Piotrowie Trybunalskim, Oddział w Tomaszowie Mazowieckim (dalej: APTM).

\footnotetext{
${ }^{6}$ Szerzej na ten temat rozprawia Kobalczyk (2005).
} 
Wyjście wojsk radzieckich na rubież Wisły, i rozpoczęcie jej forsowania (w rejonie Baranowa Sandomierskiego, Annopola, Kazimierza, Puław, Magnuszewa) dało impuls do powstania doraźnego planu budowy systemu umocnień pomiędzy Wisłą a Odrą, gdyż stanowiło to już bezpośrednie zagrożenie Rzeszy. Plan taki opracował Heinz Guderian, Naczelny Dowódca Wojsk Lądowych (Oberkomando des Heeres, dalej: OKH), wspólnie z generałem Alfredem Jakobsem, szefem wojsk inżynieryjnych przy Naczelnym Dowództwie Wojsk Lądowych. Zakładał on przede wszystkim odbudowanie dawnych niemieckich umocnionych rejonów na Wschodzie, a następnie umocnienie linii łączących te rejony oraz linii wielkich rzek. Miały one pełnić funkcję odwodów dowództwa w przypadku przełamania głównej linii obrony na Wiśle i Narwi (Hauptkampfline, dalej: HKL). Za budowę odcinka Linii Pilicy odpowiadał 102. Wyższy dowódca Saperów do zadań specjalnych. Do pracy nad budową pozycji obronnych przymusowo zatrudniano miejscową ludność cywilną, oraz osoby z obozów pracy przymusowej.

Tak powstały, poprowadzone z północy na południe, pasy obrony - OKH Stellungen, oznaczone literami od $a$ do $e$. Miały one pełnić funkcję odwodów dowództwa w przypadku przełamania głównej linii obrony na Wiśle i Narwi (Hauptkampfline - HKL). Prace nad realizacją tego planu, przy których przymusowo zatrudniano miejscową ludność cywilną, rozpoczęły się na wielką skalę w sierpniu 1944 roku i trwały aż po styczeń $1945 \mathrm{r}$.

Pierwszy na zachód od HKL pas „,a” dzielił się na linie „a1” i „a2”. Linia „a2” zwana też „Merkurstellung”, biegła od Wyszogrodu, wzdłuż Bzury, Rawki pod Skierniewice, dalej na południe i w rejonie wsi Lubocz docierała do Pilicy. Biegła w górę rzeki przez Inowłódz, Spałę, Tomaszów Mazowiecki, Sulejów, Przedbórz, następnie Miechów, Bochnię, Nowy Sącz i dalej na południe. Należą do niej umocnienia usytuowane na lewym brzegu Pilicy pomiędzy Luboczą, a Sulejowem zwane Linią Pilicy. Tomaszów, Inowłódz, Sulejów stały się węzłami oporu w obrębie pasa „,a" uzyskując szczególne znaczenie w obronie Linii Pilicy. Rola obrony tej rzeki wzrosła po uchwyceniu przez wojska radzieckie i polskie przyczółka warecko-magnuszewskiego, skąd mogło wyjść natarcie na zachód.

Podczas ofensywy styczniowej w 1945 roku na kierunku środkowej Pilicy operował Samodzielny Korpus Pancerny działający w składzie 69 Armii. Po zdobyciu Radomia otrzymał on rozkaz kontynuowania natarcia w kierunku zachodnim i sforsowania Pilicy w rejonie Tomaszowa Mazowieckiego. Dnia 18 stycznia 20 Brygada Pancerna dokonała tego w samym Tomaszowie, a 65 Brygada Pancerna na południe od Tomaszowa w rejonie Smardzewic. 20 Brygadzie Pancernej nie udało się sforsować Pilicy w rejonie Inowłodza, natomiast 36 Brygada Pancerna podeszła do Pilicy i jedna kompania czołgów przeszła po nienaruszonym moście do Tomaszowa, uderzając na dworzec kolejowy i organizując tam obronę okrężną. Główne siły brygady nie zdołały jednak sforsować Pilicy i musiały się wycofać na znaczną odległość od rzeki w skutek silnego ognia artyleryjskiego. Świadczy to o skuteczności obrony niemieckiej w Tomaszowie. Ocenia się, że rubież Pilicy nie ustępowała nadwiślańskiej. 


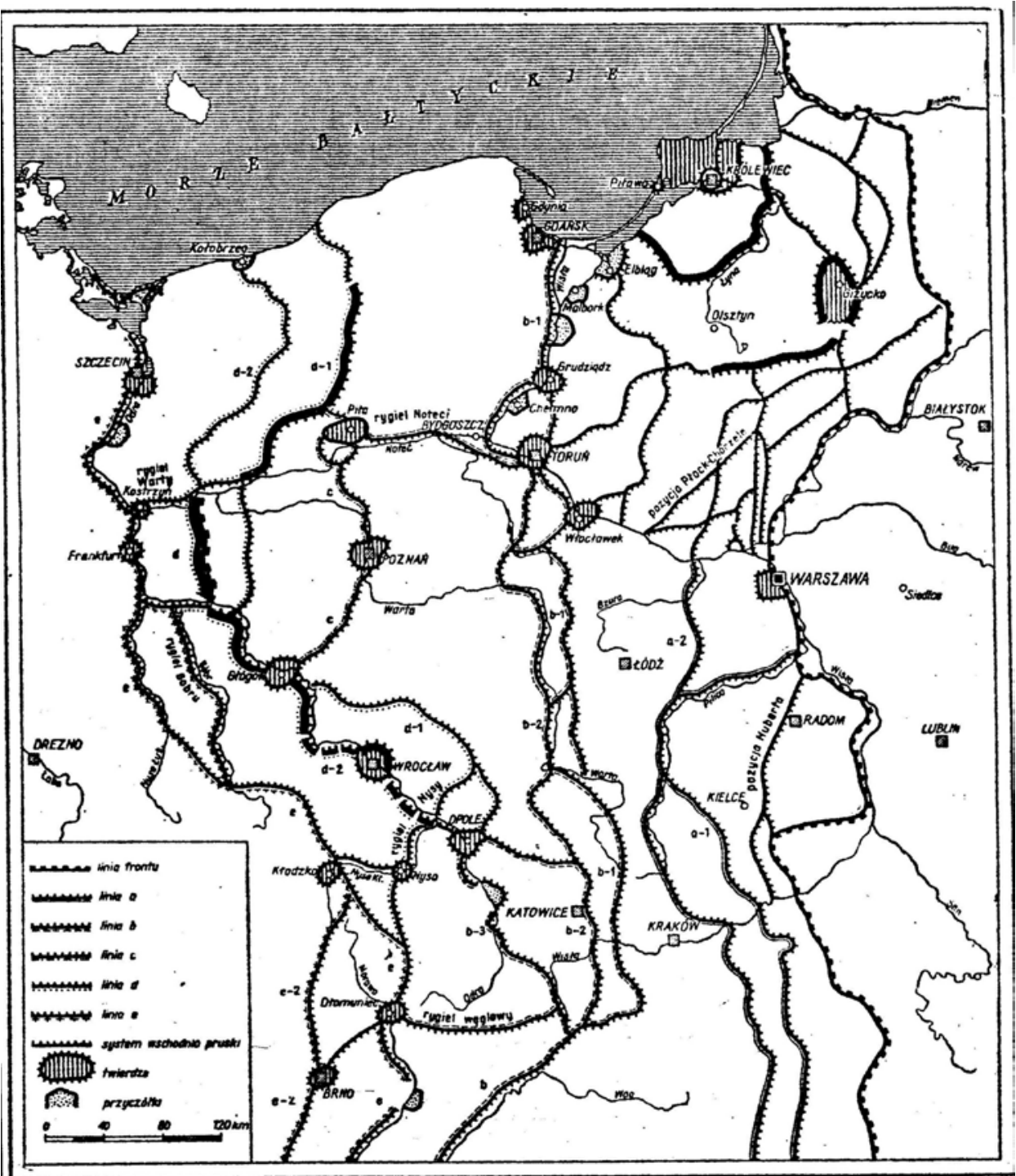

Ilustr. 2. Pasy obrony OKH Stellungen.

Źródło: Rawski (1966).

Między Inowłodzem a Tomaszowem, broniło się kilka pododdziałów z rozbitych jednostek i kilka świeżych batalionów (514, 155, 22 BSap., 136 BZap.). Były to jednostki dość liczne, wyposażone w broń maszynową i ppanc., jednak o słabym morale. W grudniu 1944 roku w Tomaszowie na przystani wioślarskiej nad Pilicą zainstalował się sztab 9 Armii z gen. Smilo von Lüttwitzem, obierając 
za kwaterę przystanie wioślarskie nad Pilicą. Po 12 stycznia generał przeniósł się do żelbetowego schronu. Wieczorem 17 stycznia sztab opuścił miasto.

Po załamaniu się prób forsowania Pilicy rano 18 stycznia nastąpiło przegrupowanie sił i ponowne natarcie po południu. 20 Brygada Pancerna, jako pierwsza sforsowała rzekę w rejonie Spały i uderzyła na Tomaszów od północnego wschodu. Główne zgrupowanie złożone z 65 i 36 Brygady Pancernej uderzyło na Tomaszów od południa. Piechota przeszła Pilicę po lodzie w okolicy Brzustówki, a następnie uruchomiono przeprawę w bród czołgów i samochodów. Po sforsowaniu rzeki jednostki pancerne ruszyły na miasto i doprowadziły do jego zdobycia w nocy z 18 na 19 stycznia 1945 roku. Brak informacji o roli fortyfikacji w tym etapie walk o miasto.

\section{Linia Pilicy (Piliza Stellung)}

Linia Pilicy składała się z głębokiej inżynieryjnej rozbudowy pasa obrony, w której stosowano m.in. rowy i zapory przeciwpancerne i przeciwpiechotne oraz drogowe, rowy strzeleckie i łączące rozbudowane w 2-3 transzeje, stanowiska ogniowe broni maszynowej, ziemianki, pola minowe, zasieki z drutu kolczastego, obiekty bojowe pozorne i obiekty maskujące, ukrycia dla ludzi i pojazdów, stanowiska ogniowe dla artylerii, zawały i przesieki leśne oraz betonowe zbiorniki wody pitnej. Pierwszą pozycję, tuż za Pilicą, osłaniały zapory z drutu kolczastego i liczne pola minowe. Przed drugą pozycją znajdował się rów przeciwczołgowy.

Tomaszów Mazowiecki, Inowłódz i Sulejów zostały zabezpieczone przed natarciem z 2-3 kierunków, ponadto w strategicznych miejscach obronę wzmocniono licznymi schronami żelbetowymi. Zbudowano tu ok. 100 schronów bojowych i biernych. Wg zarządzenia OKH, fortyfikacje należało zaopatrzyć w zapasy na okres trzymiesięczny.

Aby zapewnić łączność miały być budowane radiostacje oraz zakładane magazyny paliwa. Na prawym brzegu Pilicy, w pobliżu brodów i mostów ciągnęły się pola minowe. Wjazdy na mosty w Inowłodzu, Spale i Tomaszowie były zaminowane. Bezpiecznej ewakuacji niemieckich oddziałów służyć miały wentyle bezpieczeństwa - pasy wolne od min. Pierwszy wolny od min pas przebiegał z prawego na lewy brzeg Pilicy w okolicach osady Piekło. Drugi niezaminowany pas o szerokości dwóch czołgów, prowadził na długości 120 metrów wzdłuż odpływu Niebieskich Źródeł w Brzustówce. Wycinano całe połacie lasu w celu zapewnienia materiału do budowy umocnień jak również przygotowując przedpole do ostrzeliwań artyleryjskich. Prace fortyfikacyjne prowadzono także w korycie Pilicy, drewno obciążone kamieniami i rzucano do rzeki, tworząc przyczółki ukryte tuż pod powierzchnią wody. 


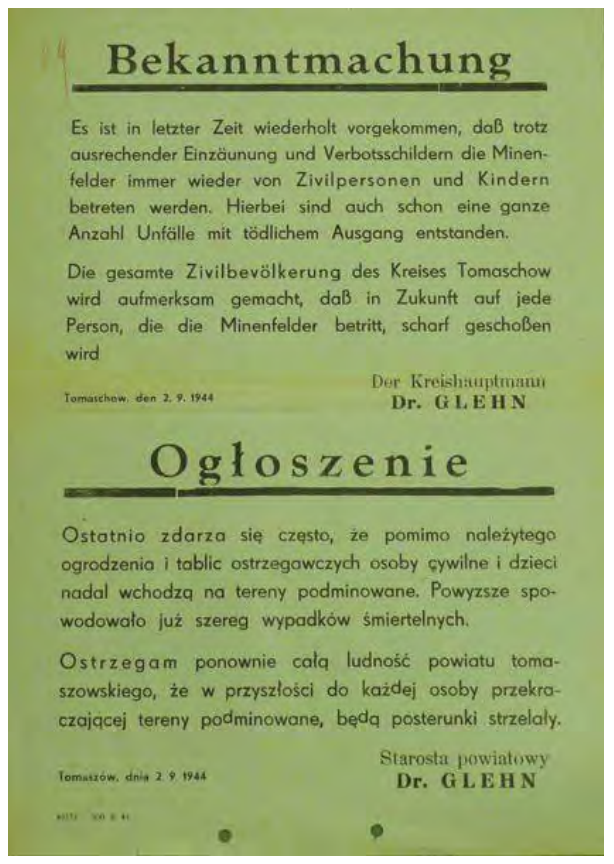

Ilustr. 3. Ogłoszenie Starosty Glehna z 2.09.1944 r.

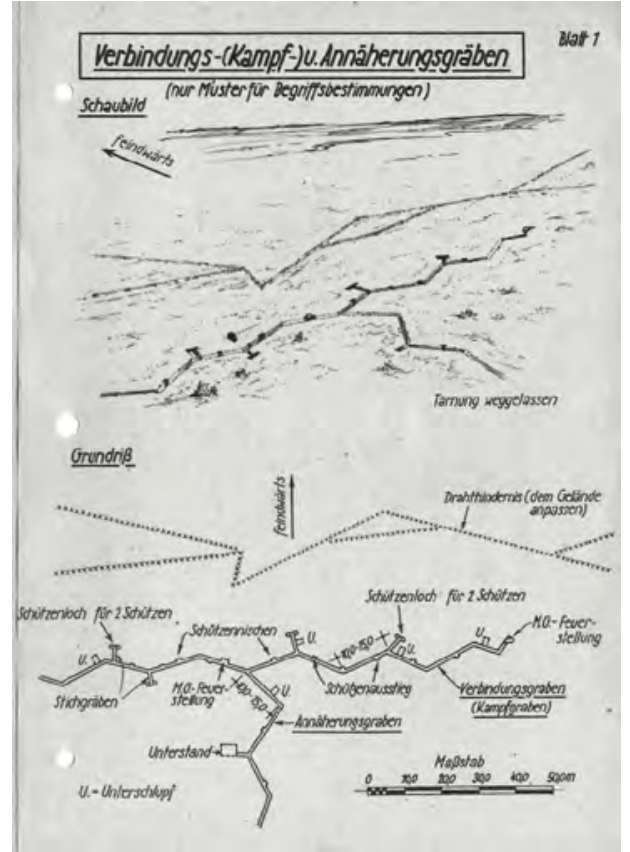

Ilustr. 4. Niemiecka instrukcja wykonywania okopów.

Źródło: APTM.

Nazywano je ślepymi mostami. Na brzegu przygotowano zapas drewna i kamieni, aby można w każdej chwili połączyć oba brzegi, zabezpieczając sobie odwrót. Umocnione węzły i punkty oporu na Linii Pilicy (omawiany odcinek), wyposażone w elementy fortyfikacji stałej (schrony bojowe i bierne) znajdują się w Luboczy, Inowłodzu, Teofilowie, Tomaszowie Mazowieckim. Linia Pilicy była pierwszą i z psychologicznego punktu widzenia, najważniejszą ufortyfikowaną linią oporu przed wkroczeniem Armii Czerwonej na tereny włączone bezpośrednio do Rzeszy.

\subsection{Typy schronów}

Obiekty znajdujące się na omawianym terenie ${ }^{7}$ stanowią przykłady ogólnych tendencji w niemieckiej inżynierii fortyfikacynej w końcowym okresie II wojny światowej. Z uwagi na szybki rozwój broni pancernej, jak również

${ }^{7}$ Z mapami i współrzędnymi GPS schronów można zapoznać się w publikacji Tomaszowskie Bunkry wydanej przez Stowarzyszenie Miłośników Architektury i Techniki Militarnej „Labirynt” (dalej: TB). 
ze względów ekonomicznych porzucono koncepcję kosztownych i rozbudowanych fortyfikacji stałych takich jak Międzyrzecki Rejon Umocniony. Skoncentrowano się raczej na budowie stanowisk strzeleckich do ognia okrężnego o niewielkich wymiarach i na budowie schronów biernych o dużej grubości ścian dla piechoty i dział. W związku z trudnościami materiałowymi, jakie Niemcy mieli pod koniec wojny, w większości obiektów wznoszonych na Linii Pilicy, stosowano liczne odstępstwa od standartowych projektów (uproszczenia i elementy zastępcze), a część z nich nie została ukończona. Na Linii Pilicy spotykamy schrony bierne (Unterstand): piechoty typu Regelbau 668, Regelbau 701 dla dział ppanc. i jeden Regelbau 621. Zagłębione w ziemi schrony LSR (Luftschutzraum), a najliczniej występują niewielkie schrony bojowe Ringstand 58c (Tobruk). Na Linii Pilicy występują również schrony Ringstand 67 oraz Kochbunker, a także betonowe podstawy dla armat przeciwlotniczych. Schron R621 oraz niektóre schrony R668 i R701 występują w wersji z dobudowanymi Ringstandami.

\subsubsection{Schron Regelbau 621}

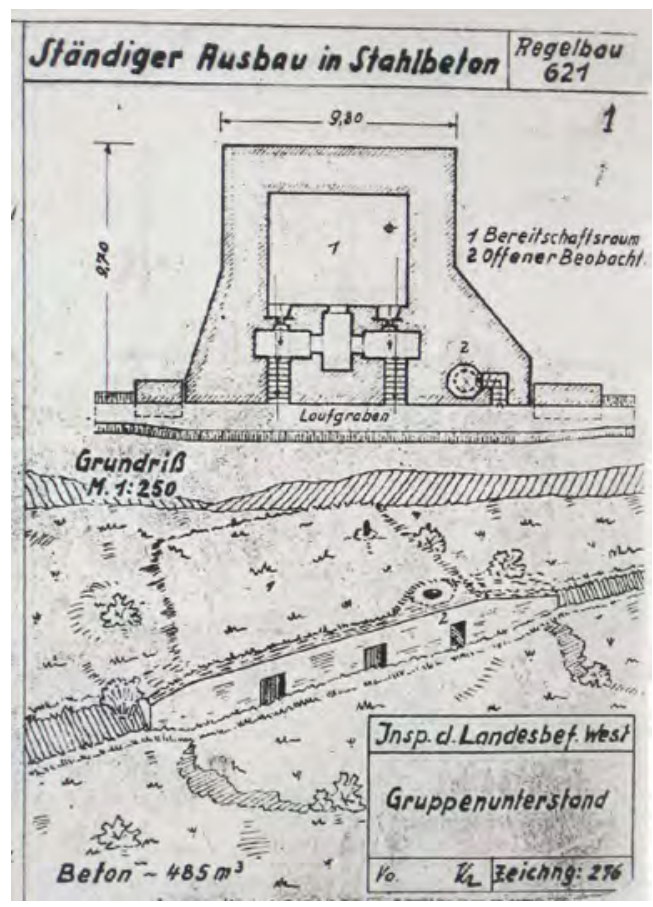

Schron Regelbau 621 - Gruppenunterstandschron bierny dla drużyny piechoty (10 żołnierzy), wykonany w odporności B1-nowe (B-neu) o grubości ścian $2 \mathrm{~m}$, w wersji z dobudowanym stanowiskiem Ringstand. Do budowy zużywano $485 \mathrm{~m}^{3}$ betonu, 23 ton prętów zbrojeniowych, 3,7 ton profili stalowych. Do pomieszczenia załogi o wymiarach $5,8 \times 3,5 \times 2,3 \mathrm{~m}$, prowadziły dwa wejścia bronione przez strzelnice $\mathrm{w}$ standartowej wersji 48P8 (tu zastosowano płytę gr. $4 \mathrm{~cm}$ strzelnicy MG 08 będącą prawdopodobnie adaptacją płyty ckm z lat 20). Do śluzy gazoszczelnej prowadziły drzwi pancerne 434P01, izbę załogi oddzielały drzwi 19P7 (tu zamontowano jedynie prowizoryczne drzwi drewniane). Schron wyposażony był w peryskop SR9, nie posiadał wyjścia awaryjnego. Na wyposażenie socjalne składało się 10 prycz mocowanych na ścianach (typ 922 i 923S), piec WT 80 i filtrowentylator Hes (1,2 lub 2,4). 


\subsubsection{Schron Regelbau 668}
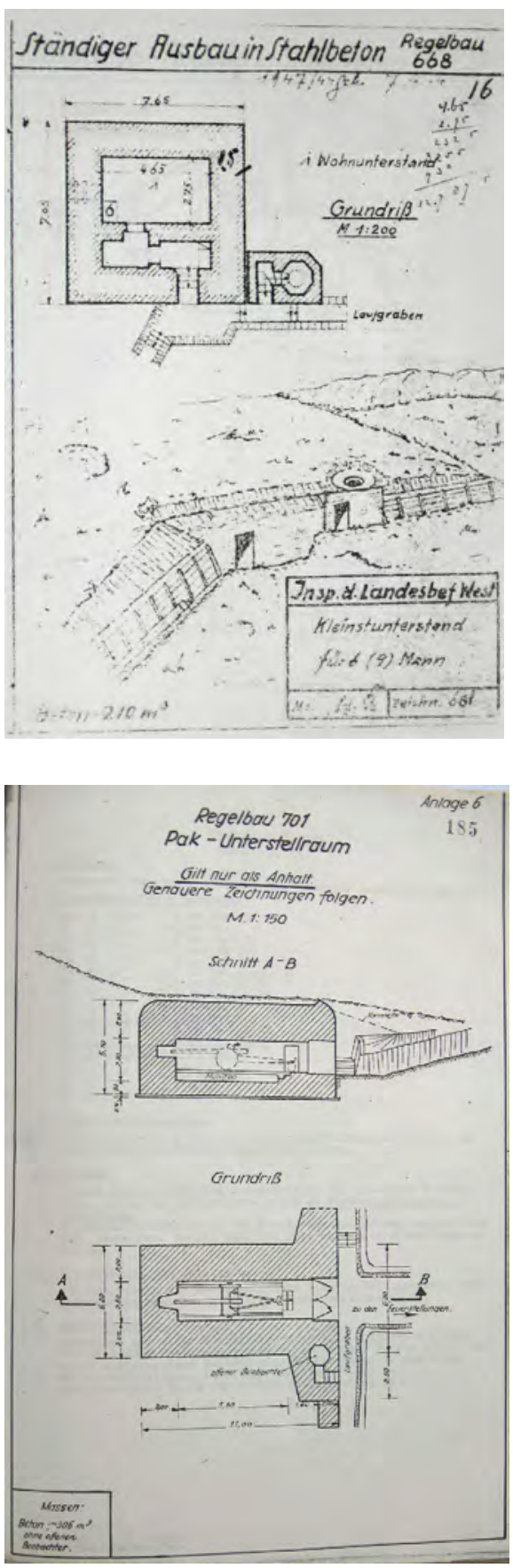

Schron Regelbau 668 - Kleinunterstand - schron bierny piechoty dla drużyny 6-9 żołnierzy, w odporności B1-alte o grubości ścian $1,5 \mathrm{~m}$, występuje w wersji z Ringstandem lub bez. Do budowy zużywano $210 \mathrm{~m}^{3}$, 9,7 t stali zbrojeniowej oraz $1,7 \mathrm{t}$ stali profilowanej. Do pomieszczenia załogi o wymiarach $4,65 \times 2,75 \times 2,10 \mathrm{~m}$, prowadziło jedno wejście. Pomiędzy przedsionkiem a śluzą gazoszczelną zamontowane były drzwi stalowe 434P01, do izby załogi prowadziły drzwi 19P7, wyjście ewakuacyjne zamykały drzwi 410P9. $\mathrm{W}$ pomieszczeniu załogi zamontowane były prycze, piec, filtrowentylator. Schron posiadał 2 pancerne osłony anten. Występował również w wersji z peryskopem.

\subsubsection{Schron Regelbau 701}

Schron Regelbau 701 - PAK-Unterstellraum ohne Nebenräume - schron bierny - garaż dla armat ppanc., plot lub haubic polowych (od 1 dużej do 4 małych), bez pomieszczeń pomocniczych, w odporności B-nowe (grubość ścian $2 \mathrm{~m}$ ). Stanowił on ochronę dla dział i ich załóg podczas ostrzału artyleryjskiego lub bombardowania. Do budowy zużywano $380 \mathrm{~m}^{3}$ betonu, $17 \mathrm{t}$ prętów zbrojeniowych oraz 2,9 t stali profilowanej. Pomieszczenie wewnętrzne o wymiarach $2,7 \times 9,6 \times 2,2 \mathrm{~m}$. posiadało w ścianach bocznych zagłębienia (prowadnice), w które można było włożyć belki drewniane stwarzając tym samym przestrzeń do przechowywania amunicji. Niektóre ze schronów posiadają rurę kominową, oraz wyjście ewakuacyjne. 


\subsubsection{Schron Regelbau 58c}

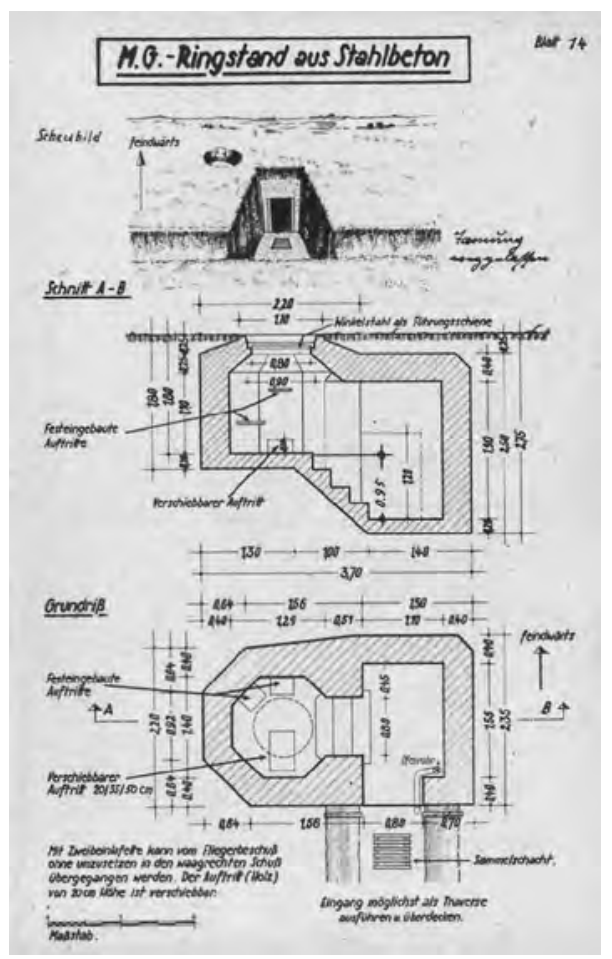

Schron Regelbau 58c - w terminologii niemieckiej Ringstand. Konstrukcja schronu oparta była na projekcie włoskiego schronu wykorzystywanego podczas walk o Tobruk w Afryce Północnej, stąd potoczna nazwa Tobruk. Betonowe stanowisko strzeleckie o niewielkich rozmiarach trudne do trafienia na 1 karabin maszynowy (MG34 lub MG42), zapewniające $360^{\circ}$ sektor ostrzału. Obiekt obsługiwany był przez 2 żołnierzy, strzelca i pomocnika (amunicyjnego). Ringstand mógł być uzbrojony także w: granatnik lub miotacz płomieni. Używano go, jako stanowisko łączności lub obserwacyjne (lornetki nożycowe, czasem niewielkie reflektory średnicy $25 \mathrm{~cm}$ ) Na Linii Pilicy wykonywane były w dwóch głównych wariantach budowlanych: z normalnym $(110 \times 155 \mathrm{~cm})$ i powiększonym $(180 \mathrm{x}$ $200 \mathrm{~cm}$ ) przedsionkiem. Oba warianty wykonywano ze ścianą zewnętrzną o grubości 40 lub $60 \mathrm{~cm}$. Powiększony typ stosowano przeważnie na pozycjach bez schronów biernych. Występują wersje ze stanowiskiem bojowym umieszczonym po prawej lub lewej stronie od wejścia. W jednym ze schronów w Tomaszowie otwór wejściowy umieszczony został w tylnej ścianie. Kilka z nich posiada dobudowaną osłonę wejścia. W przedsionkach przewidziano mały piec, a wariant powiększony wyposażony był w piętrowe drewniane prycze z 2 miejscami do spania. Karabin maszynowy ustawiano na dwójnogu opartym o stalowa obręcz zamontowaną w otworze stanowiska bojowego. Stosowano także różnego rodzaju podstawy obrotowe, forteczne, a także obrotnice ze stanowisk strzeleckich montowanych w samolotach. Połączone okopami stanowiły stałe stanowiska ogniowe umocnień broniących dróg, mostów lub obiektów strategicznych.

\subsubsection{Ringstand 67}

Ringstand 67 - stanowisko Ringstand przystosowane do zamocowania wieży czołgowej. Typ ten nie był jednoznacznym projektem, wersję budowlaną dopasowywano do rodzaju montowanych wież pancernych (stanowiska różniły 


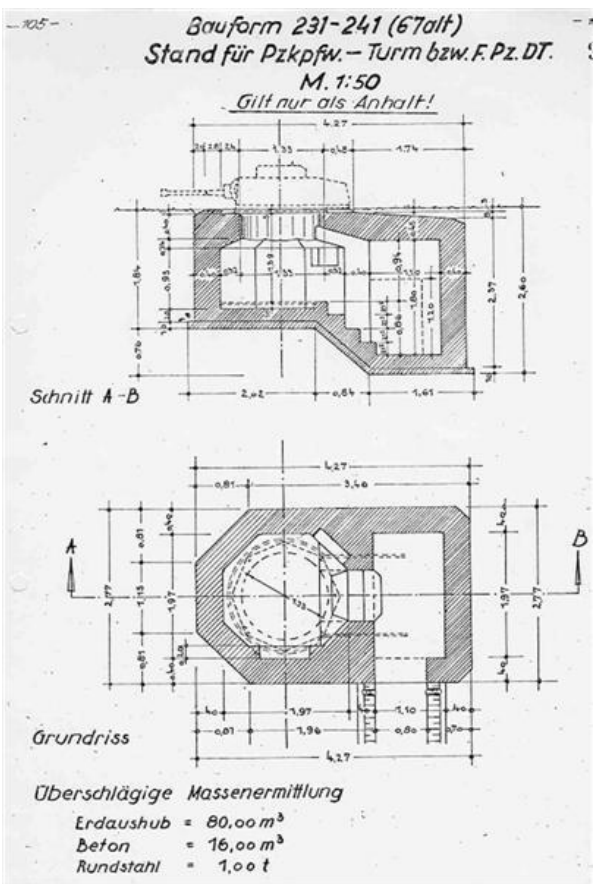

się średnicą otworu w stropie). W tego typu schronach, jako uzbrojenie główne stosowano działa i karabiny maszynowe stanowiące seryjne wyposażenie wież. Były to przeważnie wieże czołgów starszego typu, wycofanych ze służby liniowej lub pochodzące z czołgów zdobycznych. Wieża posadowiona była na obrotnicy zamocowanej do płyty pancernej przykręcanej do stropu izby bojowej. W przedsionku znajdował się mały piec i zawór klapowy wentylacji. Dwa tego typu obiekty, wyposażone w wieże od czołgów PzKpfw II powstały w Sulejowie (jeden z zachowanym korpusem wieży przetrwał do dziś).

\subsubsection{Kochbunker}

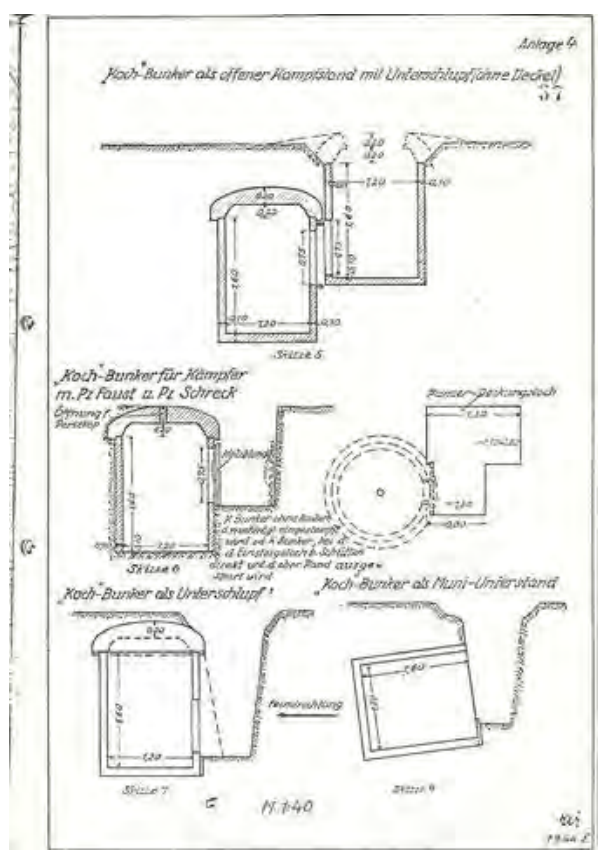

Kochbunker - mały schron jednoosobowy, Einmanbunker. (Kochtöpfe od nazwiska gauleitera Ericha Kocha, który w 1944 roku rozpoczynając przygotowania do obrony Prus Wschodnich stał się twórcą tej unikatowej konstrukcji. Ich niewątpliwą zaletą były niskie koszty wytworzenia poprzez niewielkie zużycie materiałów. Był produkowany masowo w fabrykach, jako prefabrykat i gotowy instalowany na miejscu. Jego zaletą były niskie koszty wytworzenia i niewielkie zużycie materiałów. Wchodziło się do niego bezpośrednio z okopów. Występowały w wielu wariantach - najczęściej, jako strzeleckie, (niektóre miały otwór w stropie dla posadowienia $\mathrm{CKM}$ ), obserwacyjne, położone 
w transzejach poziomo służyły, jako magazyny amunicji. Wersji kochbunkrów powstało wiele w różnych kształtach, z różnymi wymiarami, stropami i otworami strzelniczymi.

\subsubsection{Luftschutzraum (LSR)}

LSR (Luftschutzraum) system schronów przeciwlotniczych, które powstawały w ramach programu obrony przeciwlotniczej, od połowy $1943 \mathrm{r}$. Przeznaczone, jako ukrycie dla pracowników niemieckiej administracji oraz ludności cywilnej. Dwa zbudowano w okolicy dworca kolejowego, inne powstawały w zaadoptowanych piwnicach budynków. Kolejne wybudowano pod obecnym pl. Kościuszki (przeniesione w czasie rewitalizacji do Skansenu Rzeki Pilicy). W 1944 r. część z nich włączono do systemu umocnień Linii Pilicy

\section{Węzły obronne i punkty oporu na Linii Pilicy}

\subsection{Punkt oporu Lubocz}

We wsi Lubocz w miejscu gdzie linia a2 docierała do Pilicy, Niemcy zbudowali pierwszy nad rzeką punkt oporu wyposażony w elementy fortyfikacji stałej. Przede wszystkim miał on bronić przeprawy przez Pilicę, gdzie w latach międzywojennych istniały przeprawy promowe, oraz polski most saperski zbudowany w 1939 r., a więc niezbędna infrastruktura drogowa pozwalająca na sforsowanie rzeki i przejście ciężkiego sprzętu. Zabezpieczać miał także przed atakiem wzdłuż lewego brzegu Pilicy z kierunku Nowego Miasta. Rozpoczęcie ofensywy z przyczółka Warecko-Magnuszewskiego stwarzało realną groźbę, szybkiego sforsowania Pilicy i wejścia wojsk radzieckich na tyły pozycji niemieckich. Usytuowano go w widłach rzeki Luboczanki i Pilicy na wysokiej skarpie z polem ostrzału na łąki i rozlewiska w dolinie rzeki. Dodatkowo do ryglowania drogi z Nowego Miasta do Tomaszowa służyło polowe stanowisko artylerii (położone w lesie przy drodze, dziś jeszcze czytelne w terenie) oraz Ringstandy. Punkt liczy sześć schronów Ringstand 58c (pięć jest w wersji powiększonej, jeden został rozbity), oraz po jednym schronie typu Regelbau 701 i Regelbau 668.

\subsection{Węzel oporu Inowłódz}

Rolę, jaką miał pełnić Inowłódz w systemie niemieckich umocnień warunkuje jego położenie ${ }^{8}$. Stanowić miał osłonę lewego skrzydła najważniejszego węzła obrony na tzw. kierunku łódzkim, jakim był Tomaszów Mazowiecki. Przede wszystkim

\footnotetext{
${ }^{8}$ Por. Miziak (2011).
} 
miał bronić przeprawy przez Pilicę, ale także zabezpieczać przed ewentualnym natarciem wyprowadzonym lewym brzegiem Pilicy, z kierunku Nowego Miasta. W jego skład wchodziły punkty oporu w: Zakościelu, Inowłodzu oraz Teofilowie.

\subsubsection{Punkt oporu Zakościele}

Usytuowany został na wysokiej skarpie oraz wąwozie położonym na skraju lasu.

W jego skład wchodziły: schron Ringstand 58c, schron Regelbau 668 z dobudowanym Ringstandem, posiada zachowane półkoliste wyjście ewakuacyjne na strop. Obmurowanie podzielone jest na część wyjściową z zachowanymi klamrami oraz część służącą do zrzutu sadzy z przewodu kominowego, oraz schron na armatę Regelbau 701 z Ringstandem (zachowane mury oporowe nasypów przed wjazdem do środka) i basen przeciwpożarowy na najwyższym punkcie wzniesienia, o wymiarach $8,20 \mathrm{~m}$. szer. x 5,2 m. dł. x 1,3 m. gł.

\subsubsection{Punkt oporu Inowłódz}

Znajduje się w pobliżu wzgórza przy kościele św. Idziego. Oprócz schronów żelbetowych znajdują się tam umocnienia ziemne, na zachód transzeje i stanowiska strzeleckie, okrakiem na drodze do Rzeczycy ślady stanowisk dział ppanc. Na punkt oporu składają się dwa powiększone Ringstandy na wschód od kościoła św. Idziego, oraz dwa garaże Regelbau 701, jeden Regelbau 668 i basen przeciwpożarowy na północ od kościoła.

\subsubsection{Gniazdo oporu na Górze Kościuszki (Wzgórze przy cmentarzu z I w.ś.)}

Składa się z jednego powiększonego schronu Ringstand 58c z dobudowanym pomieszczeniem stanowiącym ukrycie dla liczniejszej załogi (na terenie dawnego ośrodka Elester). W pobliżu znajdowało się polowe stanowisko artylerii wyposażone w działa Flak $8,8 \mathrm{~cm}$, z których jedno zniszczyło czołg rosyjski przy moście na pilicy. Stanowisko blokowało drogę położoną poniżej.

\subsubsection{Gniazdo oporu na Ptasiej Górze (wzgórze na wprost cmentarza z I w.ś.)}

Tu powstały dwa powiększone schrony Ringstand $58 \mathrm{c}$ na północy i południu wzgórza oraz umocnienia ziemne od południa. Blokowały one drogę na południe i zachód od wzgórza.

\subsubsection{Punkt oporu Teofilów}

Punkt stanowią cztery schrony Ringstand 58c (jeden wykopany spoczywa w wyrobisku kopalni), jeden schron piechoty Regelbau 668 i trzy garaże Regelbau 701. Dwa R701 posiadają dobudowane stanowiska Ringstand, przy jednym 
z nich zachowała się droga wytaczania działa $\mathrm{z}$ betonowymi umocnieniami, a w drugim zachowane jest w podłodze okrągłe wyjście ewakuacyjna, przy tylnej zewnętrznej ścianie półokrągła osłona wyjścia. Zadaniem punktu było blokowanie drogi ze Spały do Inowłodza, oraz przejścia przez rzekę Pilicę.

\subsection{Węzeł oporu Tomaszów Mazowiecki}

Między Teofilowem, a Tomaszowem ciągnęły się jedynie umocnienia ziemne. Budowa fortyfikacji w Tomaszowie wiązała się z jego strategicznym znaczeniem. Był to ważny węzeł drogowy i kolejowy. Znajdowały się tu dwa mosty drogowe i podwójny most kolejowy (linie do Skarżyska oraz Radomia). Wybudowano tu ponad 40 obiektów zmieniając Tomaszów w miasto bunkrów ${ }^{9}$. Wszystkie schrony zbudowano na lewym brzegu Pilicy od Brzustówki do Henrykowa. W Tomaszowie budowano schrony Typu R 58c, R 668, R 701 (również w zespołach R $701+$ R 58c lub R $668+$ R 58c). Poza tym powstało kilka innych obiektów: improwizowany schron - magazyn amunicji (Henryków), betonowa podstawa pod armatę przeciwlotniczą na wale Wolbórki w pobliżu mostu kolejowego na Pilicy, zakryty betonowy zbiornik wody (nieopodal dawnej parowozowni). Pospieszne prace przy budowie schronów prowadzono intensywnie od sierpnia 1944 r., a przy ich budowie zatrudniano przymusowo mieszkańców miasta i okolic. Budowy kilku obiektów nie dokończono.

Największym i najciekawszym schronem w Tomaszowie jest Regelbau 621 przy ul. Strzeleckiej. W tym dużym, położonym na wzniesieniu niedaleko mostu przez Pilicę schronie, znajdowało się prawdopodobnie stanowisko dowodzenia baterią artylerii broniącej przeprawy w Brzustówce.

Schron Regelbau 621 od 2009 do 2013 znajdował się pod opieką Stowarzyszenia Miłośników Architektury i Techniki Militarnej „Labirynt”, które prowadziło prace rewaloryzacyjne tego obiektu. Od maja 2013 roku schronem opiekuje się Stowarzyszenie Rekonstrukcji Historycznej „Batalion Tomaszów” i dalej prowadzi prace konserwacyjne obiektu.

Słabo obsadzone tomaszowskie umocnienia powstrzymały styczniową ofensywę Armii Czerwonej zaledwie na jeden dzień. Oskrzydlone niemieckie oddziały, w obliczu okrążenia, opuściły pozycje nad Pilicą i 18 stycznia 1945 r. wycofały się z Tomaszowa w kierunku Łodzi.

W niniejszym opracowaniu pokazano jedynie schrony zachowane do dziś, lub miejsca, w których SMAiTM „Labirynt” potwierdziło istnienie schronów w czasie prowadzenia prac inwentaryzacyjnych. Wiele schronów wtopiło się w dzisiejszą, miejską infrastrukturę Tomaszowa, niektóre jednak zostały zasypane lub zniszczone podczas powojennej rozbudowy miasta.

\footnotetext{
${ }^{9}$ Zob. Bednarski M. (1995); obszerniej TB.
} 


\subsection{Węzel oporu Sulejów}

Między Tomaszowem a Sulejowem ciągnęły się umocnienia ziemne w postaci rowów przeciwczołgowych, transzei, ziemnych stanowisk strzeleckich i artylerii. W okolicach Zarzęcina zbudowano ślepy most. Aby można było szybciej usypać podwodne przyczółki, specjalnie w tym celu wybudowano dwa drewniane mosty: od strony Lubiaszowa do Zarzęcina i za Czarnym Jeziorem do Zarzęcina. Dopiero w okolicach Sulejowa Niemcy zastosowali elementami fortyfikacji stałej. Oprócz mocno rozbudowanego systemu umocnień ziemnych zbudowane zostały schrony Ringstand 58c, 67 oraz Kochbunkry. Ich zadaniem była obrona przeprawy przez Pilicę oraz bardzo ważnej drogi prowadzącej do Piotrkowa, która otwierała drogę na zachód. Schrony wybudowano od Przygłowa do Barkowic, wzdłuż brzegu Pilicy aż za most drogowy w Sulejowie, wzmocniono nimi rów przeciwpancerny we Włodzimierzowie i Przygłowie, stanowiące drugi pas obrony. Ponadto umocnienia ryglujące drogę ciągnęły wzdłuż drogi i linii kolejki wąskotorowej się od mostu na Pilicy do mostu na Luciąży w Przygłowie.

\subsubsection{Punkt oporu Nowa Wieś - Barkowice}

Punkt obejmuje pięć standardowych Ringstandów 58c zlokalizowanych na polach koło Nowej Wsi, osłaniały przeprawę przez pilicę w rejonie Barkowic. Według relacji mieszkańców w pobliżu jednego ze schronów między budynkami, znajdowało sie stanowisko artylerii. Niemcy próbując się z niego wstrzelić w przeciwny brzeg rzeki, pierwszym strzałem trafili w hełm wieży kościoła w Podklasztorzu.

\subsubsection{Punkt oporu Przyglów - lewy brzeg Luciąży}

W skład wchodzi jeden Ringstand 67 z widocznymi śrubami i otworami na mocowanie wieży czołgu, oraz trzy schrony Ringstand 58c, jeden z dobudowaną osłoną wejścia. Czwarty obiekt znajdował sie na terenie dzisiejszego boiska, ale został wysadzony. Umocnienia położone na wysokiej skarpie od Przygłowa do Barkowic. Prawdopodobnie w Przygłowie przy moście nad Luciążą, znajdował się jeszcze jeden schron Regelbau 67.

\subsubsection{Punkt oporu Włodzimierzów - wzdłuż rowu przeciwczołgowego}

Punkt stanowiło pięć schronów Regelbau 58c, obecnie jeden został przeniesiony do Skansenu Rzeki Pilicy w Tomaszowie.

\subsubsection{Punkt oporu Sulejów}

Umocnienia ciągną się od ujścia Luciąży wzdłuż Pilicy w stronę Sulejowa. W mieście schrony wzniesiono wzdłuż toru kolejki i drogi w rejonie stacji i dawnych wapienników. Punkt oporu tworzą trzy Ringstandy 58c, dwa Ringstandy 67 
i jeden Kochbunker odrestaurowany (przez Grupę Eksploracja Łódź). Jeden z Ringstandów 58c znajduje się w torowisku kolejki wąskotorowej przy wjeździe na nieistniejący obecnie most, posiada dobudowaną osłonę wejścia. Ringstand 67 umiejscowiony na skarpie nad Pilicą posiada zachowaną wieżą czołgu Pz.Kpfw. II. W pobliżu znajdowały się jeszcze dwa takie schrony, które dziś już nie istnieją.

\section{Stanowisko dowodzenia „Anlage Mitte" - kompleksy schronów w Konewce i Jeleniu}

W 1939 r., krótko po zakończeniu działań wojennych w Polsce, w Spale ulokowano najważniejsze dowództwo wojskowe na terenach okupowanych, Naczelne Dowództwo- Wschód (Oberbefehlshaber Ost, w skrócie Oberost). Dowództwo zmieniając formy organizacyjne istniało do 1943 r. Konsekwencją umieszczenia ośrodka dowodzenia w Spale była decyzja o budowie w pobliżu stanowiska dowodzenia na wypadek wojny z ZSRR. W pobliskiej Konewce oraz Jeleniu, w 1940 r., rozpoczęto supertajną budowę potężnych betonowych schronów dla pociągów sztabowych.

Miejsca do budowy ufortyfikowanych stanowisk dowodzenia wytyczono we wsiach Konewka i Jeleń, w początkach 1940 r. W Tomaszowie i Białobrzegach powstały pierwsze obozy dla robotników Organizacji Todta, oddziałów Służby Pracy RAD. Przybyło ok. 3000 robotników z różnych rejonów Niemiec i Austrii, oraz koło 1500 Włochów. Na tereny przygotowane do budowy wkroczyła firma Chemische Werke „Askania” oraz robotnicy z Organizacji Todta. W samym Tomaszowie powstało kilka niemieckich firm pracujących na potrzeby Askanii. Zatrudniały ok. 1000 pracowników, a oprócz Niemców znalazło tam pracę wielu Polaków, których zatrudniano także przy pracach pomocniczych i transporcie, ale nie mieli oni wstępu bezpośrednio na place budowy.

W Konewce oddalonej 4 kilometry od Spały pod budowę wybrano dużą leśną polanę, pozostałą po masowym wyrębie lasów jeszcze w czasie I wojny światowej (w 1916 r. powstał w Konewce duży tartak). W położonym $6 \mathrm{~km}$ na południe od Spały, Jeleniu obiekty kwatery miały powstać nieopodal małej stacji kolejowej i drogi do Spały zwanej Carskim Traktem (tędy carowie dojeżdżali od stacji w Jeleniu do swej rezydencji w Spale). Od listopada 1940 r. stacja kolejowa w Jeleniu została zamknięta dla ruchu pasażerskiego.

Schrony kolejowe różnią się nieco od siebie kształtem i długością; schron w Konewce ma 380 metrów długości i jest prosty, zaś schron w Jeleniu jest nieco krótszy - ma 355 m i kształt łagodnego łuku. Oba schrony mają przekrój ostrołuku, wewnątrz na całej długości ciągnie się półkolista nawa z torowiskiem kolejowym, z niej prowadzą zejścia do mniejszego, równoległego korytarza podzielonego stalowymi, hermetycznymi drzwiami na pomieszczenia dla obsługi 
pociągu. Po zakończeniu budowy, schrony zabezpieczały znajdujących się w nich ludzi i pociąg przed skutkami wybuchu wszelkich istniejących wówczas bomb lotniczych, chroniły również przed skutkami ataku gazowego. Obok gigantycznych schronów kolejowych usytuowano mniejsze schrony zaplecza technicznego mieszczące agregaty prądotwórcze, kotłownie i wentylatory tłoczące podziemnymi kanałami ogrzane i filtrowane powietrze do wnętrza schronu kolejowego. Inne schrony mieściły studnię, hydrofornię i zbiorniki wody. Kwatery wyposażono $\mathrm{w}$ instalacje wodociągowe, kanalizacyjne i odwodnieniowe $\mathrm{z}$ osadnikami i odstojnikami ścieków oraz zbiorniki paliwa do generatorów ${ }^{10}$. Na potrzeby kwatery zajęto również kilka, pamiętających jeszcze czasy carskie budynków w Konewce; w drewnianej willi zbudowanej pod koniec XIX w. dla carewicza Mikołaja zajęło kierownictwo budowy, później mieściła się tu komendantura kwatery, natomiast budynek mieszkalny dla służby i łowczych zamieniono na kasyno i kwatery oficerskie. Wzniesiono kilkanaście drewnianych baraków. W Konewce przy skrzyżowaniach dróg i przy torze kolejowym wykonano system umocnień ziemnych z gniazdami karabinów maszynowych, a od strony lotniska zbudowano dwa żelbetowe schrony bojowe oraz schron bierny dla oddziałów ochrony kwatery. Teren wokół kwatery był ściśle strzeżony, tak, że nawet okoliczni mieszkańcy i ludzie zatrudniani przez Niemców w Spale nie znali przeznaczenia wzniesionych obiektów. Według źródeł niemieckich do budowy kompleksów w Jeleniu i Konewce zużyto $75100 \mathrm{~m}^{3}$ betonu. Obecnie w Konewce obiekty naziemne oraz podziemne mają połączenie przez 80-metrowe przejście kanałami technicznymi udostępnione są do zwiedzania. Znajduje się tu Trasa Turystyczna „Bunkier w Konewce” z ekspozycją militariów oraz czasowymi wystawami przybliżającymi wojenną historię regionu.

Relacje świadków mówią o kilku wizytach pociągów specjalnych w Spale i Konewce. Zwracały one uwagę, gdyż w czasie przejazdów takich pociągów wprowadzano szczególne środki bezpieczeństwa w Tomaszowie i Spale, wzdłuż trasy przejazdu pociągu, w kilkudziesięciometrowych odstępach rozstawieni byli żołnierze i funkcjonariusze służby ochrony kolei (Bahnschutz). Przez pewien czas obiekty „Anlage Mitte" nie były wykorzystywane. W początkach 1942 r. rozpoczęto demontaż części urządzeń w Jeleniu i według świadków z terenu kwatery wywieziono dwa pociągi (120 wagonów) sprzętu, wyposażenia i zdemontowanych baraków.

W połowie 1944 r. wobec zagrożenia alianckimi nalotami, schrony w Jeleniu i Konewce posłużyły, jako magazyny i zakłady remontowe odzyskujące części z uszkodzonych silników lotniczych należące do tomaszowskiej filii firmy Daimler-Benz Flugmotorenwerke. Zatrudniano tam wówczas jeńców rosyjskich i robotników przymusowych z Tomaszowa i okolicznych miejscowości. Kompleks w Jeleniu znalazł się wówczas w wykazie dyslokacji niemieckich obiektów przemysłowych pod kryptonimem Goldamsel, a schronom w Konewce nadano

${ }^{10}$ Zob. Szymańska, Szymański 2012; http://www.bunkierkonewka.eu. 
kryptonim Hühn. Pod koniec wojny, w związku z bojowym wykorzystaniem lotniska koło Glinnika przez Luftwaffe, schron kolejowy i teren obok niego wykorzystano, jako skład bomb i amunicji lotniczej.

W styczniu 1945 roku Niemcy bez walki opuścili Konewkę. Schron zaminowano wykorzystując do tego celu tutaj zmagazynowane bomby. Obiektów jednak nie wysadzono, nie zdążono też wywieźć pozostałego tu wyposażenia, a 18 stycznia nieliczna załoga uciekła przed zbliżającymi się od strony Królowej Woli oddziałami 61 Korpusu Piechoty Armii Czerwonej. Usuwanie leżących w schronie bomb i amunicji polscy saperzy rozpoczęli wiosną 1945 r., a w 1946 r. zdemontowano wyposażenie schronów technicznych, wywożąc je do odbudowywanych fabryk Na początku lat 50-tych schron w Konewce wykorzystywano, jako magazyn „Centrali Rybnej”. Około 1954 r. zdemontowano również dwie pary pancernych wrót do schronu, zastępując je drewnianymi drzwiami. Od lat siedemdziesiątych do końca wieku schronami w Konewce dysponowało wojsko. W Jeleniu podobnie jak w Konewce były magazyny „Centrali Rybnej”. Zlikwidowano je w dopiero w $1990 \mathrm{r}$.

Między Konewką a Glinnikiem II (od zachodu) zachowały się dwa niewielkie schrony bojowe zabezpieczenia kompleksu, oraz betonowe podstawy wież strażniczych. Od wschodu na granicy lasu przed Królową Wolą zbudowano jedną taką wieżę. Na pobliskim lotnisku na Glinniku, gdzie obecnie stacjonuje 25 Brygada Kawalerii Powietrznej, znajduje się tam kilka małych, podziemnych schronów przeciwlotniczych.

\section{Schrony strażnicze w Glinniku}

Schrony mieszczą się na skraju lasu ok. 1 km na wschód od Glinnika, na północ od drogi Konewka - Glinnik ${ }^{11}$. Pierwszy oddalony jest od drogi ok. 250 m, drugi znajduje się na terenie byłej żwirowni ok. $1350 \mathrm{~m}$ (ocena na podstawie mapy). Od kompleksu kolejowego w Konewce oddalone są w linii prostej odpowiednio: pierwszy ok 1,8 km, drugi ok. 2,2 km. Schrony zbudowano, jako jednopoziomowe, jednoizbowe na planie przypominającym nieregularny sześciobok. Przy czym najdłuższą przekątną zorientowano według linii brzegu lasu tj. w przybliżeniu pn-pd. Grubość ścian schronów wynosi ok. $100 \mathrm{~cm}$. stropu ok. $150 \mathrm{~cm}$. a płyty fundamentowej ok. $65 \mathrm{~cm}$. Wysokość wewnątrz $195 \mathrm{~cm}$. Schrony wykonano z betonu zbrojonego prętami stalowymi gładkimi o średnicy $12 \mathrm{~mm}$. Strop zabezpieczono warstwą przeciwodpryskową z dwuteowników 240, kładzionych co $34 \mathrm{~cm}$. Między nimi położono pasy blach stalowej grubości I mm. W ścianach „od pola” znajdują się strzelnice, po trzy w każdym schronie. Strzelnice miały profil przeciwrykoszetowy i w każdej zamocowano pancerz grubości $30 \mathrm{~min}$. Najprawdopodobniej były

\footnotetext{
${ }^{11}$ Zob. Rosiński (2006).
} 
to pancerze typu 422P01. Zamocowano je niesymetrycznie w ten sposób, iż w centrum strzelnicy znajdował się główny otwór ogniowy pancerza, natomiast boczną szczelinę obserwacyjną trwale zasłaniała ściana i korzystanie z niej było niemożliwe. Nadproża strzelnic wykonano z dwuteowników 240. Każdej strzelnicy od wewnątrz towarzyszyły pewnego rodzaju parapety (podłokietniki). Ich zadaniem było ułatwienie prowadzenia ognia; broni ręcznej i lekkiej broni maszynowej. Nie ma na nich natomiast śladów ich dostosowania do montażu podstaw ckm. To oraz sposób zamontowania pancerzy w ścianach wskazuje na to, że już na etapie projektowania zrezygnowano z wyposażenia schronów w ciężką broń maszynową.

W ścianie „od lasu” wykonano wejście zamykane drzwiami pancernymi - w schronie na terenie żwirowni zachowała się ościeżnica. Wnętrze schronu w żwirowni nie nosi śladów po wyposażeniu stałym. Co ważniejsze schronie nie było żadnych innych otworów ( np. otwory wentylacyjne, wyjście awaryjne) oprócz drzwi i strzelnic. świadczy to o tym, że nie można było z niego prowadzić intensywnego i długotrwałego ognia z broni maszynowej. Na stropie schronu w żwirowni zachowały sie elementy do mocowania siatek maskujących (świńskie ogony). Schron na terenie żwirowni zachował się dobrze. Przy okazji pozyskiwania piasku osiadł o jakieś 2-3 m, mógł się również i przesunąć. W wyniku nierównomiernego osiadania lub wybuchu w środku pękł. Zachowały się w nim trzy pancerze w strzelnicach (dwa prawie kompletne) oraz ościeżnica drzwi pancernych. Schron bliżej drogi został wysadzony. Zniszczeniu uległ strop, ściany tylne i częściowo prawa przednia. Ocalały dwa pancerze w strzelnicach.

\section{Skrzynki}

W lesie niedaleko Skrzynek, w 1940 r. zbudowano cztery schrony bierne typu Regelbau 102v oraz kilka baraków. Miały tu powstać kwatera dowództwa i kwatermistrzostwa OKH (niemieckiego Naczelnego Dowództwa Wojsk Lądowych). Schrony zostały wysadzone w powietrze już po wojnie podczas testowania ładunków z pobliskiej fabryki w Niewiadowie. Obecnie można obejrzeć ich ruiny. W pobliżu, między Skrzynkami a Ujazdem, hitlerowcy zbudowali lotnisko polowe na ornych gruntach przylegających do miasteczka. Leżało ono w nieforemnym prostokącie, ograniczonym z północy drogą z Ujazdu do stacji kolejowej w Skrzynkach, z zachodu - szosą biegnącą do Tomaszowa Mazowieckiego, a ze wschodu - linią kolejową i sosnowym lasem. Jego południowo-wschodnia część ostrym klinem wrzynała się pod Tomaszów. Na wschodniej stronie, tuż przy linii kolejowej, hitlerowcy przy pomocy jeńców i okolicznej ludności, wykopali parę schronów. W nich magazynowano bomby lotnicze, amunicję i sprzęt techniczny. Lotnisko nie miało hangaru, samoloty stały pod gołym niebem. W czasie lata i zimy doskonale nadawało się ono do eksploatacji. Gorzej przedstawiała się sprawa w okresie późnej 
jesieni i w czasie wiosny, kiedy od deszczy rozmiękła ziemia. Wtedy samoloty najczęściej grzęzły w błocie aż po osie. Trawiasty pas biegł z południowego wschodu na północny zachód i miał dwa kierunki startu: 135 i 315 stopni. W zależności skąd wiał wiatr, kierunek startu i lądowania ulegał wahaniom.

\section{Podsumowanie}

Zabytki mają swoich obrońców, zarówno instytucjonalnych jak i społecznych. Teoretycznie WUKZ i liczne stowarzyszenia, towarzystwa mają jeden cel. Tylko, że część z nich kieruje się zasada pragmatyzmu, innym przyświecają idee romantyczne, a pomiędzy nimi jest rzeczywistość, a ta bywa brutalna. Zwłaszcza, gdy w ochronie zabytków ścieramy się z kwestią polityczną lub ekonomiczną. Warto ratować również takie zabytki jak obiekty architektury militarnej, którymi są schrony z czasów II wojny światowej. Wiele obiektów zostaje całkowicie lub częściowo zniszczonych. Przykładem może być schron Bauform 251 w Bielsku Białej. Na naszym terenie mamy raczej dobre przykłady. Skansen Rzeki Pilicy przeniósł do siebie dwa schrony (Ringstand 58c i Kochbunker), Trasa turystyczna „Bunkier w Konewce” również zaadaptowała u siebie dwa schrony (Kochbunker). Miejmy nadzieję, że kolejne schrony będą przenoszone, a nie burzone.

Reasumując, można stwierdzić, że zachowane obiekty fortyfikacyjne Linii Pilicy stanowią ciekawy i swoisty skansen budownictwa obronnego z konkretnego okresu, dający pojęcie o ówczesnych tendencjach w fortyfikacji niemieckiej. Mimo iż w latach wojny budowle tworzone ze znacznym nakładem sił i środków w zasadzie nie sprostały stawianym im projektowym oczekiwaniom, obecnie stanowią bezcenne źródło informacji, a także narzędzie edukacji i promocji wiedzy, zarówno z zakresu dziejów umocnień, jak i historii regionalnej. Są one również inspiracją dla licznego grona pasjonatów - rekonstruktorów i badaczy amatorskich. Ich współpraca ze środowiskiem historyków może zaowocować wymiernymi korzyściami zarówno dla nauki, jak i świadomości historycznej tomaszowian. Na kartach tak krótkiej pracy trudno omówić w pełni wszystkie aspekty jakże złożonego tematu. Niemniej jednak stanowi ona pewien punkt odniesienia do dalszych badań, a możliwie i formę inspiracji dla Czytelnika.

\section{BIBLIOGRAFIA}

Bednarski M. (1995), Fortyfikacje niemieckie w Tomaszowie Mazowieckim z 1944 roku, „Fortyfikacja”, t. 3.

Dudek M., Sadowski J. (2006), Pancerze fortyfikacji niemieckich z lat 1934-1941. Atlas pancerzy, Inforteditions, Gliwice.

http://www.bunkierkonewka.eu (dostęp: 15.10.2020).

http://www.schrony.eu (dostęp: 15.10.2020). 
Hubka M. (2016), „Anlage Mitte” - „Piliza Stellung”. Idea, budowa i wykorzystanie niemieckich umocnień z lat II wojny światowej w rejonie Tomaszowa Mazowieckiego, [w:] A. Olejko, P. Korzeniowski (red.), Człowiek i technika na polach bitew wojen światowych, Instytut Historii Uniwersytetu Rzeszowskiego, Rzeszów, s. 69-79.

Hubka M., Ordak M., Wróbel A. (red.) (2010), Historia Tomaszowa Mazowieckiego w źródłach archiwalnych. Dokumenty z zasobu Archiwum Państwowego w Piotrkowie Trybunalskim, Oddziat w Tomaszowie Mazowieckim, Polskie Towarzystwo Historyczne, Koło w Tomaszowie Mazowieckim; Archiwum Państwowe w Piotrkowie Trybunalskim, Oddział w Tomaszowie Mazowieckim, Tomaszów Mazowiecki.

Kaufmann J.E., Kaufmann H.W., Jurga R.M. (2011), Fortyfikacje III Rzeszy, niemieckie umocnienia i systemy obrony w II wojnie światowej, Rebis, Poznań.

Kędryna A.M., Jurga R.M. (1999), Wyposażenie socjalne obiektów fortyfikacji niemieckiej 19331944, Donjon, Kraków.

Kobalczyk A. (2005), Wojna zatrzymana w Pilicy, Imax, Łódź.

Łach W.B. (2002), System obronny na Warmii i Mazurach w czasie II wojny światowej, Towarzystwo Przyjaciół 1 Mazurskiej Brygady Artylerii im. Gen. Józefa Bema, Węgorzewo.

Łach W.B. (2014), XIX- $i$ XX-wieczne fortyfikacje Warmii i Mazur w edukacji i turystyce historycznej, doświadczenia i wnioski, [w:] A. Drzewiecki, Ł. Różycki (red.), Militaria w edukacji historycznej, t. 2, Wydawnictwo Napoleon V, Gdynia.

Maszkowski P. (2010), Byt sobie schron..., „Odkrywca”, nr 9(140).

Matuszak T. (2014), ,,Kiedy się wypetnity dni...”. Polska i Polacy w realiach okupacyjnej rzeczywistości, [w:] Z. Matuszak, T. Matuszak, M. Hubka (red.), Kiedy się wypelnity dni... Wrzesień 1939 r. na ziemi piotrkowskiej, Naczelna Dyrekcja Archiwów Państwowych, Archiwum Państwowe w Piotrkowie Trybunalskim, Warszawa-Piotrków Trybunalski.

Miziak M. (2011), ,, Tobruk”, ,wyfedrowany”w Inowłodzu, „Odkrywca”, nr 7(150).

Ordak M. (2012), Obwód Armii Krajowej w Tomaszowie Mazowieckim, [w:] T. Matuszak (red.), Oblicza Podziemia. Studia i szkice z dziejów ZWZ-AK, Archiwum Państwowe w Piotrkowie Trybunalskim, Muzeum w Tomaszowie Mazowieckim im. Antoniego hr. Ostrowskiego, Piotrków Trybunalski-Tomaszów Mazowiecki.

Podsiadło R. (2012), Fortyfikacje niemieckie na linii OKH Stellung A2: Proszowice-Hebdów-Świniary-Krzyżanowice, R. Podsiadło, Kraków.

Podsiadło R. (2014), Niemieckie fortyfikacje Stellung a2 i ich przełamanie w styczniu 1945 r. na linii Raby, Szreniawy i Pilicy, Agencja Wydawnicza CB, Warszawa.

Rawski T. (1966), Niemieckie umocnienia na ziemiach polskich w latach 1919-1945, „Studia i Materiały do Historii Wojskowości”, t. 12, cz. 1.

Rosiński W. (2006), Schrony strażnicze w Glinniku, „Forteca”, nr 20-21.

Rudź W. (1980), Z problemów polityki gospodarczej okupanta hitlerowskiego w powiecie tomaszowskim (1939-1945), „Rocznik Łódzki”, t. 29.

Szymańska M., Szymański J. (2002), Kwatery Główne Hitlera oraz niemieckie stanowiska dowodzenia w Polsce. Przeglad niemieckich kwater dowodzenia w Europie, „Labirynt '96”, Łódź.

Szymańska M., Szymański J. (2009), W krainie wielkich bunkrów. Hitlerowskie ośrodki dowodzenia na Mazurach, Imax, Łódź.

Szymańska M., Szymański J. (2012), Konewka, Jeleń. Niemieckie stanowisko dowodzenia „Anlage Mitte”, Imax, Łódź.

Tomaszowskie Bunkry - opisy, mapy, zdjęcia, GPS. Linia Pilicy, Anlage Mitte (b.r.), Stowarzyszenie Miłośników Architektury i Techniki Militarnej „LABIRYNT”, Konewka.

Wróbel A. (2015), Powiat tomaszowski w latach 1939-1945. Zarys dziejów, [w:] A. Wróbel (red.), Obrazy września. Region i społeczeństwo w czasie II wojny światowej, Archiwum Państwowe, Gminny Ośrodek Kultury w Ujeździe, Piotrków Trybunalski-Ujazd. 


\title{
Pawet Grad
}

\section{GERMAN FORTIFICATIONS OF TOMASZÓW MAZOWIECKI AND THE SURROUNDING AREA. TYPES AND KINDS OF SHELTERS}

\author{
(Summary)
}

The article presents the military fortifications built by the Germans during World War II near Tomaszów Mazowiecki in the years 1940-1944, especially the long belt of fortifications called Piliza Stellung, although it focuses on a relatively short section running along the Pilica River from Sulejów to Inowłódz and Lubocz (near Rzeczyca). The paper discusses various types of shelters, and more broadly presents the preserved military fortifications in Tomaszów Mazowiecki and the railway shelter complexes (“Anlage Mitte") in Konewka and Jelenia.

Keywords: World War II, military fortifications, German occupation, the Pilica River, shelters, Tomaszów Mazowiecki. 